\title{
Evaluation of Factors Affecting Adult Immunization
}

\author{
Memet Taşkın Egici ${ }^{1}$, () Beray Gelmez Taş², (i) Müfide Arzu Özkarafakılı², (i) Güzin Zeren Öztürk² \\ ${ }^{1}$ Department of Family Medicine, University of Health Science, Haydarpasa Training and Research Hospital, Istanbul, Turkey \\ ${ }^{2}$ Department of Family Medicine, University of Health Scienc, Sisli Hamidye Etfal Training and Research Hospital, Istanbul, Turkey
}

\begin{abstract}
Introduction: Vaccination is the most effective application in preventing from infections. In recent years, vaccination is still inadequate in adults despite the fact that there is a great deal of effort in childhood vaccination. We aimed to evaluate the vaccination status of adults and the factors that affected them.

Methods: In this descriptive study, a questionnaire consisting of 15 items exploring sociodemographic variables, the status of vacciniation and the factors influencing the vaccination was applied to adult individuals who admitted to family medicine clinics of Sisli Hamidiye Etfal Training and Research Hospital. The data were entered into the statistical program and analyzed. Results: The average age of participants was $61.40 \pm 13.43$. The proportion of participants who had adult vaccinations was $49.1 \%$ ( $n=108$ ), average age of them were $60.68 \pm 13.47$ and $66.7 \%$ were female. There was no significant relationship between age, sex, and education status of the adult vaccination's. The most important factor affecting the vaccination was physician 's recommendation (73\%; $n=86)$. the second factor was the effect of the media. Among the reasons for not having the vaccine, physician recommendation $(70 \% ; n=80)$ was found to be the first important factor also, the second factor was disbelief of need of vaccine.

Discussion and Conclusion: In our study, it was determined that adult vaccination was inadequate and mostly influenza vaccine was used in adults. It was found that the physician's recommendation was the most common cause of the decision to get or not to get vaccinated. Since most frequently vaccinations were performed in family medicine units, physicians' mainly family physicians' recommendations will increase the rate of vaccination in adulthood. Thus, effort should be given to increase the awareness of physicians. We believe that raising the awareness of the community within the scope of health literacy will also positively affect adulthood vaccination.

Keywords: Adulthood vaccination; awareness; family medicine; health literacy; physician's recommendation.
\end{abstract}

$V^{2}$ accination is the most effective method of protection against infections. Infections that can be prevented by vaccination cause more than 30 thousand deaths per year in many developed countries ${ }^{[1,2]}$. Expanded Immunization Program (EIP) is being carried out in our country and immunization against 13 diseases in childhood is done free of charge mainly by family physicians. With in the frame of EIP program, tree-doses of combination vaccine (five componenet) was applied in $78 \%$ of the children in 2002 which raised up to $98 \%$ in $2016^{\text {[3] }}$.

Family medicine encompasses preventive health care in both concept and duty definition ${ }^{[4]}$. For this reason the role of family physicians service is great in increasing the vaccinations. Considering the cases where the main branch specialist (family medicine, internal medicine) and the specialists of the side branches propose influenza and pneumococcal vaccination to the patients, the vaccination of influenza vaccine is more often preferred than the vac-

Correspondence (iletişim): Memet Taşkın Egici, M.D. Department of Family Medicine, University of Health Science, Haydarpasa Training and Research Hospital, Istanbul, Turkey

Phone (Telefon): +90 2165423232 E-mail (E-posta): megici@gmail.com

Submitted Date (Başvuru Tarihi): 07.07.2018 Accepted Date (Kabul Tarihi): 24.07.2018 
cination of pneumococcus. It has been seen that female physicians and the physicians who were vaccinated, recommended vaccination more frequently ${ }^{[5]}$.

Since the family medicine implemantation started in 2010, the rate of childhood immunization has increased significantly in Turkey. Although vaccination is considered childhood vaccination, adult vaccination is as important as childhood vaccination ${ }^{[6]}$. Vaccination in adults include different goroups like healthy adults and special case (pregnancy, immunosuppression or insufficiency, chronic diseases, travel, military service, health workers etc.) ${ }^{[7]}$.

Today, advances in healthcare and technology have increased the life expectancy estimated at birth, leading to an increase in the elderly population. In our country, the elderly population doubled from 2000 to $2016^{[8]}$. Increased incidence of chronic diseases with aging and weakening of the immune system and diminished protection of childhood vaccinations have brought adult vaccination to the fore ${ }^{[9]}$. Adult vaccination reduces infections by $60 \%$ and death by $80 \%{ }^{[10]}$.

Although adult vaccination is so important, it has not been performed adequately both in our country and in the world ${ }^{[11]}$. In this study, it has been emphasized that having adequate information about the vaccine, informing the people about vaccination safety, providing vaccination opportunity free of charge, expansion of general immunization programs and physicians' recommendations would increase adult vaccination rates ${ }^{[12]}$.

We also aimed to propose solutions by evaluating the vaccination status of the adults and the factors affecting the vaccination.

\section{Materials and Methods}

The study was a cross-sectional, descriptive study which was conducted on individuals aged over 18 years who were referred to the University of Health Scinences Sisli Hamidiye Etfal Training and Resaarch Hospital (TRH) Family Medicine outpatient clinic for any reason, between 19 June -02 July 2018. Sisli Hamidiye Etfal TRH Ethics Board approved the study (2018/2025).

Using a face-to-face survey method a 15-item information form including the socio-demographic data, vaccination status and factors influencing vaccination of the participants was directed to the participants after their consent was obtained. It was stated that they could mark more than one choice for the vaccines and factors influencing their immunization or non-immunization status.

The data were entered into the statistics program. In descriptive statistics, numerical variables were expressed as numbers and percentages, and categorical variables were indicated as mean, standard deviation, minimum and maximum. Mann- Whitney $U$ test was used for the comparison between two independent groups of numerical variables with non-normal distribution.The rates of categorical variables between groups were compared with chi-square analysis. Statistical significance level of alpha was accepted as $\mathrm{p}<0.05$.

\section{Results}

A total of 220 participants including 140 (63.6\%) female and $80(36.4 \%)$ male individuals were included in the study. The mean age of the participants was $61.40 \pm 13.43$ years. Of the participants, $15 \%(n=33)$ were illiterate, $66.8 \%(n=147)$ were high school and lower educated, and $18.2 \%(40)$ had university education. $49.1 \%(n=108)$ of adult participants had any one of the adult vaccinations. The mean age of the adult vaccinated was $60.68 \pm 13.47$ years, most of them were high school and lower educated (64.8\%).

As seen in Table 1, no statistically significant relation was found between age, gender and educational status of any of

Table 1. The relation between sociodemographic data and adult vaccination status

\begin{tabular}{|c|c|c|c|c|c|}
\hline & \multicolumn{2}{|c|}{ Vaccinated $(n=108)$} & \multicolumn{2}{|c|}{ Non-vaccinated $(n=112)$} & \multirow[t]{2}{*}{$\mathbf{p}$} \\
\hline & $\mathbf{N}$ & $\%$ & $\mathbf{N}$ & $\%$ & \\
\hline \multicolumn{6}{|l|}{ Age } \\
\hline $18-64$ & 59 & 49.17 & 61 & 50.83 & $p>0.05$ \\
\hline$\geq 65$ & 49 & 49 & 51 & 51 & \\
\hline \multicolumn{6}{|l|}{ Gender } \\
\hline Female & 73 & 52.1 & 67 & 47.9 & $p>0.05$ \\
\hline Male & 36 & 45 & 44 & 55 & \\
\hline \multicolumn{6}{|l|}{ Educational level } \\
\hline Illiterate & 15 & 14 & 18 & 16 & $p>0.05$ \\
\hline High School and lower educated & 70 & 65 & 77 & 69 & \\
\hline University & 23 & 21 & 17 & 15 & \\
\hline
\end{tabular}


the adult vaccinees $(p>0.05)$. When the data were examined, it was determined that most frequently influenza (44.5\%; $\mathrm{n}=98$ ) then tetanus, pneumococcal and hepatitis vaccines were applied in order of decreasing frequency (Fig. 1).

People over the age of $65(n=100)$ have been specifically investigated as they are risk groups. In this group, $45.37 \%$ $(n=49)$ proportion of the vaccinated was not statistically significant with gender although they were higher in women. ( $50 \%$ in women, $n=29,47,61 \%$ in men, $n=20, p>0.05$ ). All of the vaccine recipients in this group had received flu vaccination $(n=49)$, followed by pneumococcal $(6 \%)$, tetanus $(3 \%)$, and hepatitis $B$ vaccines (3\%). The rate of influenza vaccination was statistically significantly higher $(p<0.05)$ in all age groups and over 65 years of age compared to immunization rate of other vaccines.

Although participants could mark more than one item in the questionnaire, when the answers were examined, the physician's recommendation was the most frequently reason that positively effected the vaccination rate $(73 \%$, $\mathrm{n}=86$ ). This is followed by, though at a lower rate, information gathered from media, and believing in the protection role of the vaccine (Fig. 2). Besides, the most frequent reason for not participating in the vaccination was lack of physician's recommendation. $(70 \%, \mathrm{n}=85)$. The other justifi-

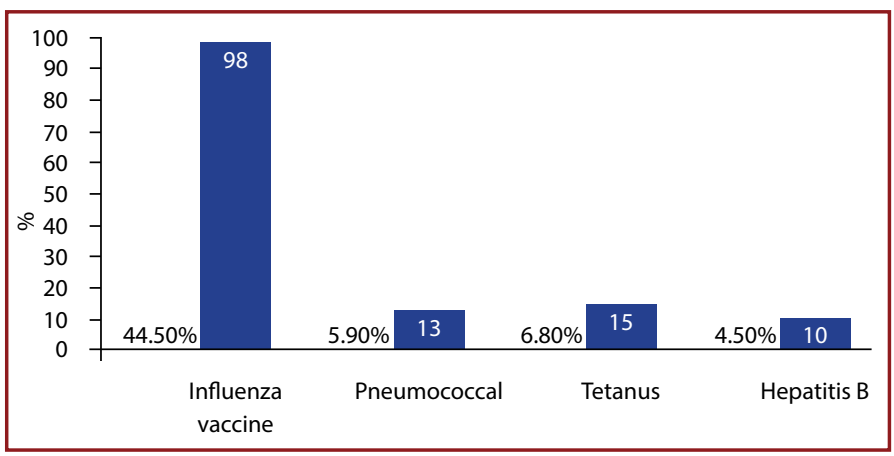

Figure 1. Adult vaccination status of the participants.

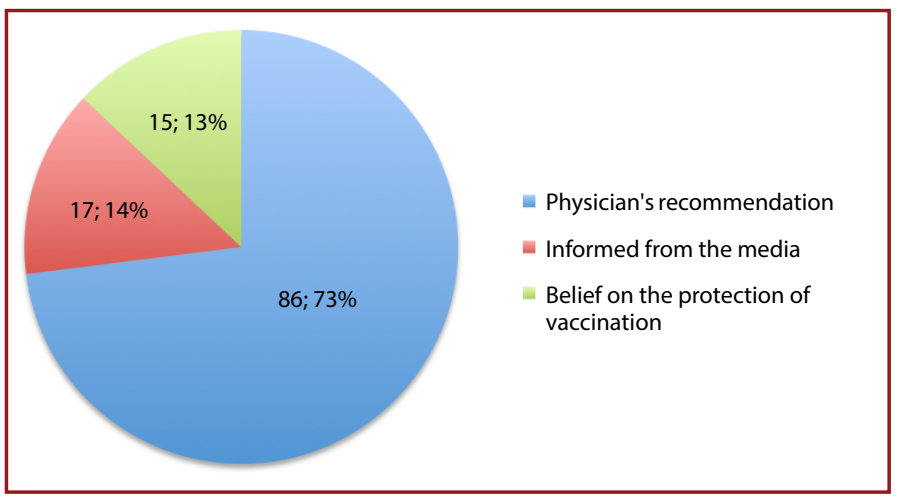

Figure 2. Factors that have positive influence on vaccination in participants. cations of the participants for not being vaccinated were as follows: the participants thought that they did not need to be vaccinated $(27 \% ; n=22)$, they were not convinced about the reliability of the vaccine, disbelieved in the benefit of the vaccine, or thought that vaccination was expensive (Fig. 3).

\section{Discussion}

As in childhood vaccination programs, adult vaccination schedules and vaccination protocols are available according to age and special circumstances. Adult vaccination is grouped by the Centers for Disease Control and Prevention (CDC) according to age groups (19-26, and over 50 years of age), special health conditions, pregnancy, travel and immigrant vaccination ${ }^{[13]}$. An adult immunization guide was published in 2016 by Turkey Infectious Diseases and Clinical Microbiology Specialty Society, and similar vaccination recipient groups were examined.

In a study conducted in adults aged 18 years and elderly in our country, it has been stated that indicated percentages of the patients had not seropositivity to diphtheria (65\%), tetanus (69\%), whooping cough $(90 \%)$, and respective percentages of patients required immunization against tetanus (78\%), whooping cough $(90 \%)$, and diphtheria $(96 \%)^{[14]}$. As seen in this study, although the need for adult immunization is high, the vaccination coverages are still not at desired levels.

As a result of the study conducted with 100 participants in five family health centers in Antalya Province in 2012, it was determined that $41 \%$ of adult participants were not vaccinated at any time of their life and $59 \%$ had vaccinated at least once ${ }^{[11]}$. In our study, $49.1 \%$ of participants had received at least one adult vaccination.

In a study conducted with individuals (women, 56.42\%) over 65 years of age (mean age, $71.36 \pm 5.3$ years) whose

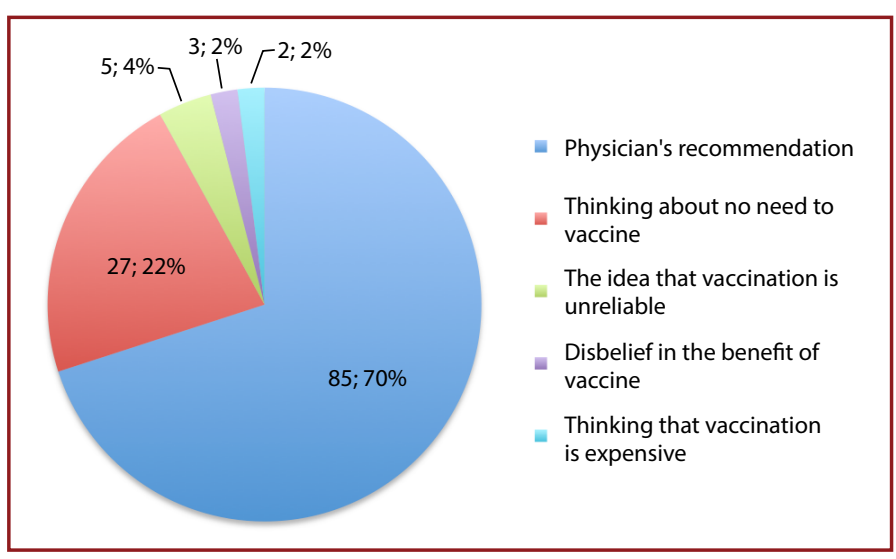

Figure 3. The factors that effect the choose not to vaccinate of the participants. 
results were published in $2018,35.62 \%$ of the participants had been vaccinated at least once, and $64.42 \%$ of them had not been vaccinated excepting childhood vaccinations ${ }^{[15]}$. In our study, rate of vaccination among participants of both sex over 65 years of age was $45.37 \%$ with a statistically insignificant higher rate among female participants In some studies, higher vaccination rates among women may be due to higher female population in the age group and this issue should be examined in more detail ${ }^{[16]}$.

Although there is an indication for vaccination for all individuals in this age group irrespective of the presence of a chronic disease, vaccination rate is low. In another study, the reasons for the vaccination levels below the desired levels in the elderly population were listed as follows; lack of information, misconceptions and beliefs of the physicians about the subject, and giving priority to treatment services rather than vaccination in the advanced age group ${ }^{[17]}$. According to the USA data for the year 2013, adults above the age of 65 were most frequently vaccinated against pneumococci ${ }^{[18]}$ with a rate of $60 \%$. However in our study, we found that adults above 65 years of age, most frequently vaccinated against influenza, while only $6 \%$ of them received pneumococcal vaccine. In another study carried out in Mersin, influenza vaccine was found to be the most frequently used vaccine type ${ }^{[9]}$.

According to 2008 data of Aegean Region Working Group of Turkish Society of Internal Medicine, diabetics were immunized against pneumococcus $(0.1 \%)$ and influenza (9.1\%). In this study, it is noteworthy that the rate of pneumococcal vaccination is low ${ }^{[19]}$. This may be due to the fact that the influenza vaccination is cheap and easily available, but also because of the increasing level of awareness about flu epidemics every year due to relevant news released by media.

Thus; in a study conducted in 5 different European countries (Germany, Italy, Spain, the United Kingdom and France), vaccination rates and causes of influenza over the age of 14 were investigated, and $55.8 \%$ of vaccinated persons reportedly thought that influenza is a serious disease [20]. In another study it was found that levels of awareness about influenza vaccination were higher when compared with other vaccinations ${ }^{[21]}$.

When we looked at studies that investigated the reasons of vaccination and nonvaccination, only $68.2 \%$ of those who had received pneumococcal vaccination stated that they were vaccinated upon physician's recommendation and $31.8 \%$ of them were vaccinated by their own will or according to their children's recommendation ${ }^{[22]}$. In a study performed in 1988, physician's recommendation was indicated as the most common determinative factor for vaccination, or nonvaccination [23].

In another study, also similar to our study, physician's recommendation was found to be the most important factor effecting the vaccination rates ${ }^{[24]}$. In a study published in 2016, the first justification for vaccination was penetrating stab wounds followed by the physician's recommendation. The reasons for nonvaccination in decreasing order of frequency were lack of knowledge, and physician's recommendation, and disbleief in its benefit.

Higher frequency of lack of knowledge, and disbelief in the beneficial effects of vaccination in some studies, and, thinking of vaccination as an unnecessary procedure in our study( the $2^{\text {nd }}$ most frequent cause of nonvaccination) overlap with the thought that an important part of the adult population in Turkey has insufficient health literacy ${ }^{[25]}$.

The low rate of thinking that the vaccine is expensive indicates that the cause of nonvaccination is not economic. It has been thought that the institutions concerned should try hard to increase the awareness of the community about vaccination, and the adult vaccination should occupy much more space in the education curriculum in order for the physician's recommendations to come to a sufficient level.

\section{Conclusion}

In our study, it was determined that adult vaccination was inadequate and the most frequently applied adult vaccine was influenza vaccine. We also found that the physician's recommendation was the most common cause of the decision to get vaccinated or not. Since vaccinations are performed most frequently in family medicine units, the recommendations of all physicians, predominantly family physicians will increase adult vaccination rates.

It is important to perform studies to increase the awareness of physicians. However, we believe that the immunization program should be expanded and followed, and that the related institutions, especially the Ministry of Health, should inform the individuals properly within the scope of health literacy and also their efforts to raise their awareness will affect vaccination in adults favourably.

\section{Limitations of the Study}

Limitations of the study can be summarized as follows: The study was performed in a tertiary hospital, and in a population more needs vaccination. Besides, the questionnaire form contained closed-end questions. 
Ethics Committee Approval: The study was approved by Ethics Committee of University of Health Sciences, Şişli Hamidiye Etfal Training and Research Hospital (19.06.2018 - 2025).

Peer-review: Externally peer-reviewed.

Authorship Contributions: Concept: M.T.E., B.G.T., A.M.Ö., G.Z.Ö.; Design: M.T.E., B.G.T., A.M.Ö., G.Z.Ö.; Data Collection or Processing: M.T.E., B.G.T., A.M.Ö., G.Z.Ö.; Analysis or Interpretation: M.T.E., B.G.T., A.M.Ö., G.Z.Ö.; Literature Search: M.T.E., B.G.T., G.Z.Ö.; Writing: M.T.E., B.G.T., G.Z.Ö.

Conflict of Interest: None declared.

Financial Disclosure: The authors declared that this study received no financial support.

\section{References}

1. National Vaccine Advisory Committee. A pathway to leadership for adult immunization: recommendations of the $\mathrm{Na}$ tional Vaccine Advisory Committee: approved by the National Vaccine Advisory Committee on June 14, 2011. Public Health Rep 2012;127 Suppl 1:1-42. [CrossRef]

2. Zucs P, Buchholz U, Haas W, Uphoff H. Influenza associated excess mortality in Germany, 1985-2001. Emerg Themes Epidemiol 2005;2:6. [CrossRef]

3. T.C. Sağlık Bakanlığı. Sağlık istatistikleri yıllığı. Sağlık Araştırmaları Genel Müdürlüğü; 2016. Available at: https://dosyasb. saglik.gov.tr/Eklenti/13183,sy2016turkcepdf.pdf?0, Accessed Jul 26, 2018.

4. Dikici MF, Kartal M, Alptekin S, Çubukçu M, Ayanoğlu AS, Yarış F. Concepts, task in family medicine and history of the discipline: medical educatıon [Article in Turkish]. Turkiye Klinikleri J Med Sci 2007;27:412-8.

5. Nichol KL, Zimmerman R. Generalist and subspecialist physicians' knowledge, attitudes, and practices regarding influenza and pneumococcal vaccinations for elderly and other high-risk patients: a nationwide survey. Arch Intern Med 2001;161:2702-8. [CrossRef]

6. Kunze U, Groman E. Immunizing is not only a children's matter! : Why vaccinations are also important for adults [Article in German]. Wien Med Wochenschr 2017 Sep 13 [E-pub ahead of print], doi: 10.1007/s10354-017-0598-7. [CrossRef]

7. T.C. Sağlık Bakanlığı Temel Sağlık Hizmetleri Genel Müdürlüğü, Genişletilmiş Bağışıklama Programı Genelgesi, Genelge 2009/17. Available at: https://dosyasb.saglik.gov.tr/Eklenti/ 1117,gbpgenelge2008pdf.pdf?0. Accessed Jul 26, 2018.

8. Türkiye İstatistik Kurumu. Yaş gruplarına göre nüfus 20002016 Türkiye İstatistik Kurumu Verileri, Available at: www.tuik. gov.tr/PrelstatistikTablo.do?istab_id=1588. Accessed Jul 26, 2018.

9. Bal H, Börekçi $\mathrm{H}$. Investigation of Adult Vaccination Status and Effecting Factors in People 65 Years and Over Registered to A Family Health Center in Mersin City [Article in Turkish]. İstan- bul Med J 2016;17:121-30. [CrossRef]

10. Mehta B, Chawla S, Kumar V, Jindal H, Bhatt B. Adult immunization: the need to address. Hum Vaccin Immunother 2014;10:306-9. [CrossRef]

11. Aşık Z, Çakmak T, Bilgili P. Knowledges, attitudes and behaviours of adults about adult vaccines [Article in Turkish]. Türk Aile Hek Derg 2013;17:113-8. [CrossRef]

12. Alici DE, Sayiner A, Unal S. Barriers to adult immunization and solutions: Personalized approaches. Hum Vaccin Immunother 2017;13:213-5. [CrossRef]

13. Centers for Disease Control and Prevention (CDC). Vaccine Information for Adults. Available at: https://www.cdc.gov/vaccines/ adults/rec-vac/index.html. Accessed Jul 7, 2018.

14. Türkiye EKMUD. Erişkin Bağışıklama Rehberi. Istanbul; 2016. Available at: http://meramtip.com.tr/kalite/dosyalar/rehberler/eriskin-bagisiklama/EriskinBagisiklamaRehberi.pdf. Accessed Jul 26, 2018.

15. Mutlu HH, Çoşkun FO The Incidence and Awareness of Vaccination Among People Aged 65 and over Applied to a Family Medicine Outpatient Clinic [Article in Turkish]. Ankara Med J 2018;18:1-13. [CrossRef]

16. Türkiye İstatistik Kurum. Verileri 2016. Available at: http:// www.tuik.gov.tr/UstMenu.do?metod=temelist. Accessed Jul 26, 2018.

17. Abramson ZH, Levi O. Is performance of influenza vaccination in the elderly related to treating physician's self immunization and other physician characteristics? Prev Med 2008;47:550-3.

18. Willams WW, Lu PJ, O'Halloran A, Bridges CB, Kim DK, Pilishvili $\mathrm{T}$, et al. Vaccination Coverage Among Adults, Excluding Influenza Vaccination - United States, 2013. Available at: https://www.cdc.gov/mmwr/preview/mmwrhtml/ mm6404a6.htm. Accessed Jul 26, 2018.

19. Türk İç Hastalıkları Uzmanlık Derneği Ege Çalışma Grubu Raporu. Available at: http://www.tihud.org.tr/main/content?re$\mathrm{f}=2$ \&child=179. Accessed Jul 26, 2018

20. Topaç O. Ülkemizde erişkinlere yönelik aşı uygulamaları. 6. Ulusal Aşı Sempozyumu. 21-25 Ekim Ankara, 2015. p. 52-63.

21. Turhan Ö. Pnömokok aşısı. Kuwait Medical Journal 2010;42:135-8.

22. Centers for Disease Control and Prevention. Morbidity and mortality weekly report 1988. Available at: https://www.cdc. gov/mmwr/preview/ind1988_su.html. Accessed Jul 26, 2018.

23. Szucs TD, Müller D. Influenza vaccination coverage rates in five European countries-a population-based cross-sectional analysis of two consecutive influenza seasons. Vaccine 2005;23:5055-63. [CrossRef]

24. Blank PR, Schwenkglenks M, Szucs TD. Vaccination coverage rates in eleven European countries during two consecutive influenza seasons. J Infect 2009;58:446-58. [CrossRef]

25. Durusu-Tanrı̈ver M, Yıldırım HH, Demiray-Ready FN, Çakır B, Akalın HE. Türkiye Sağlık Okuryazarlığı Araştırması. 1st ed. Ankara: Sağlık-Sen Yayınları; 2014. 